\title{
Pengembangan Sistem Pendidikan Pesantren dalam Perubahan Sosial
}

\author{
Mujamil Qomar
}

Prof Dr Mujamil Qomar MA adalah Ketua STAIN Tulungagung. Jl Mayor Sujadi Timur No 46 Plosokandang Kedungwaru Tulungagung

******

Naskah diterima 30 Desember 2009. Revisi pertama, 10 Januari 2010, revisi kedua 10 Februari 2010 dan revisi terakhir 15 Maret 2010.

\begin{abstract}
Pesantren as a system of education has reciprocity with the other system. Pesantren education system changes seen in the pattern of adaptation which may range from a very gradual adaptation to the change very responsif. The adaptation of changes that occur the question is whether the boarding school on the subject or object position. When included in the formal areas, mobility was still limited to boarding school graduates in the sector, the religious department, and then only limited, if compared with other education. For that, the next boarding schools not only prepare the formal sector is limited, but must meet the needs of the open in the informal sector such as public and private.

Keywords; development, educational system, pesantren, social change.

Abstrak

Pesantren sebagai suatu sistem pendidikan memiliki timbal balik dengan sistem diluarnya. Perubahan sistem pendidikan pesantren nampak pada pola adaptasi yang beragam, mulai dari adaptasi
\end{abstract}


yang sangat gradual sampai kepada perubahan yang sangat responsif. Dalam melakukan adaptasi terhadap perubahan yang terjadi persoalannya adalah apakah pesantren pada posisi subyek atau obyek. Ketika masuk dalam wilayah formal, mobilitas lulusan pesantren masih terbatas hanya di sektor departemen agama, dan itu pun hanya terbatas, bila dibandingkan dengan pendidikan lainnya. Untuk itu, ke depan pesantren tidak hanya menyiapkan pada sektor formal yang terbatas, tetapi harus memenuhi kebutuhan yang terbuka di sektor informal seperti masyarakat dan swasta.

Kata Kunci: pengembangan, sistem pendidikan, pesantren, perubahan sosial

\section{PENDAHULUAN}

Pesantren merupakan lembaga pendidikan yang sampai saat ini menarik perhatian. Selain di Jawa, pesantren sudah mulai tersebar di berbagai kepulauan Indonesia. Penggunaan istilah pesantren tidak hanya di Jawa, tetapi juga dipakai di luar Jawa bagi lembaga serupa. Pesantren juga bukan hanya di desa tetapi sekarang telah berkembang di kota-kota, sehingga pesantren tidak selalu bersifat rural tetapi juga mulai urban. Hal ini menunjukkan pesantren telah berkembang dengan pesat dan melakukan "ekspansi" menuju wilayah yang semakin luas.

Daya tarik pesantren itu terutama ketika diperhatikan dari kecenderungan masyarakat global yang condong mengikuti pola-pola kehidupan modern yang dipengaruhi budaya Barat. Budaya ini diproyeksikan mempengaruhi jalan berpikir, cara bertindak dan gaya kehidupan seluruh masyarakat di dunia ini, dan melemahkan tradisi yang tidak sejalan dengan pola kehidupan Barat. Maka munculnya pesantren yang begitu subur terutama belakangan ini memberikan kesan mematahkan dan mementahkan kecenderungan masyarakat global tersebut, setidaknya dalam konteks Indonesia.

Di samping itu, pesantren ternyata menawarkan materi pendidikan yang sangat varian. Ada pesantren yang menekankan ilmu alat, ilmu fiqh, tasawuf, ilmu al-Qur'an dan lain-lain. Penekanan pada materi tertentu ini didasarkan pada keahlian kiainya, 
dan kebebasan kiai utuk menawarkan pola-pola pendidikan sesuai dengan seleranya. Bahkan variasi pesantren itu tidak hanya menyangkut penekanan materi pendidikannya, tetapi juga menyangkut kepemilikan lembaga, pola kepemimpinan, sikap terhadap modernisasi, sikap terhadap ilmu-ilmu umum, hingga keterlibatan dalam perpolitikan nasional.

Berdasarkan pertumbuhan yang sangat signifikan dengan berbagai variasi yang ditawarkannya, pendidikan pesantren dituntut agar menjadi lembaga pendidikan Islam yang potensial dalam membangun sumberdaya manusia Indonesia, sehingga dapat berpartisipasi mengantarkan pencapaian peradaban dan kebudayaan yang unggul serta pembentukan masyarakat madani.

\section{KETAHANAN PESANTREN}

Sebagai lembaga pendidikan sekaligus lembaga dakwah, pesantren telah hadir pada abad ke- 1.5 seiring dengan masuknya Islam ke Indonesia. Namun ada yang menyebutkan bahwa berdirinya pesantren itu pada abad ke-18. Apabila teori pertama yang benar berarti usia pesantren sekitar enam abad (600 tahun), dan jika teori kedua yang benar berarti usianya mencapai sekitar tiga abad (300 tahun). Bila mendasarkan pada teori kedua saja berarti usia pesantren telah mencapai sekitar enam kali lipat usia rata-rata orang Indonesia. Sebuah usia yang sangat tua untuk ukuran usia lembaga pendidikan.

Usia yang panjang itu, telah dimanfaatkan pesantren berpartisipasi dalam bidang dakwah, pendidikan dan sosial. Dalam bidang pendidikan, pesantren telah berperan melakukan bimbingan dan didikan kepada para santri mukim dan santri kalong atau santri nglajo (santri yang tidak menginap di pesantren, mereka berangkat dari rumah dan pulang ke rumah sehabis pengajian di pesantren). Di samping itu, biasanya pesantren juga melayani pengajian orang-orang tua (dewasa) yang berasal dari sekitar pesantren itu sendiri. Didikan atau bimbingan yang diberikan kepada santri muda maupun santri dewasa itu untuk membentuk kepribadian yang shaleh terutama dalam rangka beribadah kepada Allah. 
Pendidikan yang dilaksanakan pesantren ini dahulu dapat memenuhi kebutuhan masyarakat desa. J.F.G. Brumud sebagaimana dikutip Pradjarta Dirdjosanjoto, menyatakan bahwa jauh sebelum sekolah-sekolah umum mulai memasuki pedesaan Jawa pada akhir abad ke-19, pengajaran agama di langgar atau masjid untuk tingkat dasar, dan di pesantren untuk tingkat lanjut merupakan satu-satunya lembaga pendidikan yang tersedia bagi penduduk pribumi di pedesaan. ${ }^{1}$ Hal ini menunjukkan betapa peran pesantren dalam memproduk tokoh-tokoh agama dan elit pedesaan.

Pendidikan pesantren ini pernah dipertimbangkan oleh kolonial Belanda untuk dijadikan model pendidikan yang diberlakukan bagi masyarakat pribumi daripada Belanda harus menyiapkan model pendidikan khusus untuk penerapan politik etis. Namun akhirnya tidak terjadi karena sistem pembelajarannya dipandang kurang baik (kurang memberdayakan). Kemudian pada saat Belanda menerapkan politik etis itu, pesantren menjadi pesaing utama.

Dalam pelaksanaannya, pendidikan yang dilaksanakan pesantren tidak bisa dipisahkan dari misi dakwah. Sebaliknya dalam dakwah selalu terkandung nilai-nilai pedagogis, yang sengaja mendidik masyarakat beriman, beribadah, dan berperilaku yang baik. Pendidikan pesantren sebagai sarana dakwah, sedang dakwah sebagai salah satu jalur mendidik masyarakat. Dakwah yang dilakukan pesantren ini sebagai perwujudan dari amar ma'ruf nahi munkar sebagaimana sering dipesankan alQur'an kepada umat Islam, di samping upaya menindaklanjuti anjuran Nabi ballighû 'anniy walau ayat (sampaikanlah dariku walau satu ayat).

Dalam bidang sosial-politik, keterlibatan kiai bukan hal yang asing lagi. Sejak pertama kali pesantren berdiri hingga sekarang kiai pesantren senantiasa terlibat politik baik politik untuk kepentingan dakwah, politik untuk menghadapi penguasa

'Pradjatta Dirdjosanjoto. 1999. Memelihara Umat Kiai Pesantren Kiai Langgar di Jawa. Yogyakarta: LKiS, h. 140 
yang tiran, maupun politik untuk mengejar kekuasaan. Bahkan dalam melawan penjajah, Sartono Kartodirdjo menilai hampir semua perlawanan terhadap penjajah pada abad ke-19 selalu dimobilisasi atau setidaknya didukung pesantren. Perang-perang besar seperti perang Diponegoro, perang Paderi, perang Banjar, sampai perlawanan-perlawanan lokal yang meledak di berbagai daerah dikendalikan oleh tokoh-tokoh atau alumni pesantren. ${ }^{2}$

Keterlibatan pesantren saat ini dalam sosial-politik justru menimbulkan kesan atau penilaian yang negatif (citra yang tidak sedap), padahal dahulu juga terlibat sejak masa paling awal. Hanya saja memang ada perbedaan mendasar berkaitan dengan motif berpolitik itu. Bila kiai-kiai pesantren dahulu terlibat dalam politik semata-mata untuk dakwah, kemerdekaan dari penjajah, atau perlawanan terhadap kedzaliman penguasa lokal. Sedangkan saat ini keterlibatan mereka dalam politik semata-mata untuk mengejar kekuasaan dan materi, sehingga mengesankan citra materialistis.

Adapun keterlibatan pesantren dalam bidang sosial-ekonomi merupakan kepedulian pesantren dalam memecahkan problemproblem kehidupan masyarakat sekitar baik yang dikonsultasikan langsung pada kiai atau tidak dikonsultasikan. Sementara itu, ekonomi juga mendapat perhatian pesantren baik untuk kepentingan internal pesantren maupun eksternal dalam hal ini masyarakat sekitar yang pada umumnya memang lemah ekonominya.

Demikian, pesantren telah melintasi waktu yang sangat panjang berikut pengalamannya yang bermacam-macam dan telah berpartisipasi memecahkan problem umat pada berbagai aspek kehidupan baik pendidikan, dakwah, sosial-politik dan ekonomi, maupun aspek lainnya seperti sosial-budaya, sosial religius, pembangunan dan lain-lain. Tapi pesantren tetap menampakkan sebagai lembaga pendidikan hingga saat ini yang

\section{h. 131}

2Sartono Kartodirdjo. 1977. Sejarah Nasional. Jakarta: Balai Pustaka, 
tumbuh subur di Indonesia meskipun menghadapi gelombang modernisasi dan globalisasi yang tersebar di seantero dunia.

Keberadaan pesantren yang begitu kokoh hingga kini dapat dipandang unik. Seorang peneliti dari Amerika yang salah sangka (kecelik = bahasa Jawa) terhadap pesantren. Ia mengira pesantren itu tinggal bekas-bekas bangunan, ternyata masih ramai oleh para santri yang belajar ngaji. Abdurrahman Wahid pernah membuat perbandingan bahwa pada masa silam, pesantren di Indonesia dapat merespon tantangan-tantangan zamannya dengan sukses. Sedang sistem pesantren yang dikembangkan oleh kaum sufi baik di Malaysia maupun Thailand bagian utara sekarang ini senantiasa merana ditekan sistem sekolah model Barat. ${ }^{3}$ Demikian juga kasus yang sama terjadi di Turki. Sistem pendidikan model pesantren tidak tahan menghadapi gempuran sekularisasi yang dilancarkan Musthofa Kemal al-Taturk.

Perbandingan ini menunjukkan ketahanan pesantren menghadapi gelombang modernisasi, dan tentunya ada strategi tertentu yang menjadi faktor bertahan dalam menghadapi tekanan sistem sekolah sekuler dari Barat. Menurut Wahid, ketahanan pesantren itu disebabkan pola kehidupannya yang unik; ${ }^{4}$ Bagi Sumarsono Mestoko, ketahanan ini disebabkan telah melembaganya pesantren di dalam masyarakat; ${ }^{5}$ Azyumardi Azra menilai ketahanan pesantren disebabkan oleh kultur Jawa yang mampu menyerap kebudayaan luar melalui proses interiorisasi tanpa kehilangan identitasnya. ${ }^{6}$

${ }^{3}$ Abdurrahman Wahid, "Pondok Pesantren Masa Depan", dalam Marzuki Wahid, Suwendi dan Saifuddin Zuhri(penys.). 1999. Pesantren Masa Depan Wacana Pemberdayaan dan Transformasi Pesantren. Bandung: Pustaka Hidayah, h. 19-20

"Abdurrahman Wahid, "Pesantren Sebagai Subkultur" dalam M. Dawam Rahardjo (ed). 1995. Pesantren dan Pembaharuan, Jakarta: LP3ES, h. 43

${ }^{5}$ Sumarsono Mustoko, et.al. 1996. Pendidikan di Indonesia dari Jaman ke Jaman. Jakarta: Balai Pustaka, h. 232

${ }^{6}$ Azyumardi Azra, "Surau di Tengah Krisis: Pesantren dan Perspektif Masyarakat", dalam M. Dawam Rahardjo (ed.). 1985. Pergulatan Dunia Pesantren Membangun Dari Bawah. Jakarta: LP3ES, h. 173 
Hasan Langgulung mengamati ketahanan pesantren itu sebagai akibat dari pribadi kiai yang menonjol dengan ilmu dan visinya; ${ }^{7}$ Sedangkan menurut Kiai Ali Ma'shum, ketahanannya adalah akibat dampak positif dari kemampuan melahirkan berbagai daya guna bagi masyarakat. ${ }^{8} \mathrm{Hal}$ ini mengisyaratkan bahwa penyebab internal lebih dominan memberikan konstribusi terhadap ketahanan pesantren dibanding dengan penyebab eksternal Ini berarti pesantren memiliki potensi yang luar biasa dalam menangkal arus dan gelombang modernisasi pendidikan yang telah, sedang dan akan bergulir menawarkan berbagai perubahan.

\section{RESPON PESANTREN TERHADAP PERUBAHAN}

Ketahanan pesantren menghadapi gelombang modernisasi bukan tanpa masalah. Ada masalah pelik yang dihadapi pesantren yang membutuhkan pemecahan yang tuntas. Seiring dengan pergumulannya di tengah-tengah kehidupan modern belakangan ini terutama menghadapi sekolah sekuler.

Masalah pelik tersebut muncul karena di satu sisi pesantren memiliki identitasnya dan berupaya mempertahankan identitasnya itu. Pesantren sebagai lembaga pendidikan yang didirikan kiai untuk menanamkan dan memperdalam ajaran Islam melalui serangkaian kitab-kitab kuning yang rata-rata memuat ketentuan-ketentuan tentang keimanan, ibadah dan perilaku yang baik atau akhlak karimah. Dengan pengertian lain, pendidikan pesantren berorientasi pemberdayaan masyarakat dengan bekal dalam menghadap Allah atau bekal untuk akhirat. Sedangkan pada sisi lain, terutama setelah kemerdekaan, banyak berdiri sekolah sekuler di sekitar pesantren yang mengajarkan ilmuilmu umum berkaitan dengan pengembangan sains dan teknologi baik yang diselenggarakan pemerintah maupun masyarakat. Dengan kata lain, sekolah sekuler ini berorientasi kekinian

${ }^{3}$ Hasan Langgulung. 1988. Pendidikan Islam Menghadapi Abad ke21. Jakarta: Pustaka al-Husna, h. 75

${ }^{8}$ Ali Ma'shum. 1995. Ajakan Suci, Editor: ISmail S. Ahmad, M. Yoenus Noer dan Nadirin, ttp: LTN-NU DIY, h. 108 
atau material. Bahkan tantangan yang dirasakan paling berat dari model sekolah sekuler itu adalah akses bagi lulusan-lulusannya untuk mendapatkan pekerjaan baik sebagai pegawai negeri maupun pegawai swasta di berbagai perusahaan, yang dapat mengangkat kesejahteraan hidupnya.

Pada 1950-an ada gerakan pendidikan yang dimobilisasi pemerintah untuk mengakselerasi kecerdasan masyarakat dengan didirikan sekolah-sekolah umum sebagai bentuk kebijakan popularisasi pendidikan, sehingga gelombang pendidikan ini menghantam eksistensi pesantren. Kasus yang hampir sama dialami pesantren pada 1970-an bersamaan dengan gencargencarnya sekulerisasi memasuki Indonesia. ${ }^{9}$

Pada masa-masa tersebut merupakan masa yang sulit bagi pesantren, karena menghadapi dilema serius. Dalam kasus 1950an misalnya, banyak pesantren kecil gulung tikar. Sedangkan pesantren-pesantren besar masih bertahan hidup dengan cara memasukkan atau mendirikan sekolah-sekolah umum ke dalam pesantren, sehingga banyak pesantren besar yang menempuh cara ini. Implikasinya di berbagai pesantren besar, pengajian kitab kuning dengan model pembelajaran lama tetap dipertahankan dan menyelenggarakan pendidikan dengan mengikuti kurikulum pemerintah dan pendekatan pembelajaran yang baru, yang tentu berbeda dari model pembelajaran lama tersebut.

Cara ini tampaknya harus ditempuh pesantren, karena pesantren harus menentukan sikap. Dari berbagai sikap yang mungkin ditempuh, agaknya sikap mengikuti kecenderungan masyarakat secara umum yang dipilih karena menguntungkan masa depan pesantren meskipun harus mengorbankan pendiriannya semula. Untuk menggambarkan keadaan ini sebagaimana dikutip Azra, Karel A. Steenbrink melukiskan situasi tersebut sebagai menolak sambil mengikuti.10

9Mujamil Qomar. 2005. Pesantren dari Transformasi Metodologi Menuju Demokratisasi Institusi. Jakarta: Erlangga, h. 14

${ }^{10}$ Azyumardi Azra. 1999. Pendidikan Islam Tradisi dan Modernisasi Menuju Millenium Baru. Jakarta: Logos Wacana IImu, h. 99 
Pada zaman penjajahan Belanda, kalangan pesantren menolak sistem pendidikan atau sistem pembelajaran yang menggunakan meja, bangḳu, papan tulis, dan sebagainya. Namun setelah pesantren terdesak pada 1950-an, sistem pembelajaran yang selama ini ditolak itu kemudian diikuti. Sikap menolak sambil mengikuti itu oleh kalangan pesantren juga terjadi pada berbagai kasus lainnya seperti sikap mereka terhadap kehadiran TV berwarna; program Keluarga Berencana (KB); pakaian celana, jasa dan dasi; dan kajian kitab-kitab kuning karangan ulama non Syafi'iyah di pesantren.

Sikap pesantren tersebut menimbulkan pertanyaan mendasar, mengapa terjadi perubahan sikap secara drastis tersebut, dari sikap menolak kemudian tiba-tiba mengikuti atau setidaknya mentoleransi? Agaknya yang dijadikan pertimbangan kalangan pesantren tidak lagi faktor ilmiah, tetapi faktor-faktor lainnya seperti faktor politik, emosi, dan kefanatikan yang berlebihan sehingga menyebabkan rapuhnya suatu pendirian.

Dalam menghadapi pendidikan sekuler, pesantren menghadapi berbagai desakan baik menyangkut manajemen, kepemimpinan, sistem pendidikan, institusi, kurikulum dan metode. Akhirnya terjadi transformasi manajemen; transformasi kepemimpinan dari kepemimpinan individual kiai menuju kepemimpinan kolektif yayasan; transformasi sistem pendidikan dari sistem pendidikan yang bercorak independen berubah menjadi sistem pendidikan adaptif dan terikat; transformasi institusi dari sekedar masjid dan asrama (pondok) mengembang dengan menambah madrasah, sekolah dan perguruan tinggi; transformasi kurikulum dari penyajian materi-materi keislaman, ibadah dan akhlak mengembang dengan menambah materi umum dan ketrampilan; dan transformasi metode dari metode-metode tradisional berubah menuju metode-metode kombinatif. ${ }^{11}$

Perubahan-perubahan dalam pola pendidikan di pesantren itu menurut Abdurrahman Wahid disebabkan dua hal, yaitu: pertama, keinginan sangat kuat pada permulaan abad ke-20 untuk

"Qomar, Pesantren, h. 27-153 
menerapkan sistem sekolah pada pendidikan di pesantren yang dimulai beberapa pesantren di Sumatra dan pesantren Tebuireng Jombang; dan kedua, pergeseran secara halus tujuan pendidikan di pesantren dari penciptaan pengertian merata tentang ilmuilmu pengetahuan agama berubah menjadi pendalaman ilmu-ilmu pengetahuan agama untuk dijadikan landasan menempuh karir tertentu yang umumnya sebagai tenaga pengajar agama. Akibatnya, semakin kuatnya keinginan untuk menciptakan tenagatenaga elite dalam ilmu keagamaan di beberapa pesantren, sehingga muncul kebutuhan penegrian madrasah yang mereka miliki. $^{12}$

Perubahan-perubahan pola pendidikan di pesantren tersebut pada akhirnya dapat mengikis kemandirian pesantren yang semula memiliki otoritas secara leluasa dalam menentukan model dan corak pendidikan sesuai dengan keinginan kiai, berangsur-angsur - terutama dalam batas-batas tertentu- menjadi serba terikat oleh kebijakan penyeragaman yang dikenal dengan kebijakan sistemalisasi pendidikan baik menyangkut tujuan intitusional, kurikulum, metode pembelajaram maupun evaluasi.

Hal ini dalam pandangan Wahid dinilai sebagai krisis identitas. Dia menegaskan bahwa lantaran perubahan itu sistem pendidikan pesantren mengalami krisis identitas luar biasa. Di satu pihak, pesantren tetap memiliki watak populisnya lantaran elastisnya program pendidikan individual minimal dalam pengajaran ekstra kurikuler berbentuk pengajian; Di pihak lain, kecenderungan untuk menumbuhkan pendidikan berwatak elitis juga berjalan cukup kuat. Krisis identitas ini sebagai akibat dari kesulitan mendamaikan kedua watak yang saling bertentangan ini hingga sekarang belum teratasi. ${ }^{13}$

Dengan demikian, respon pesantren terhadap perubahanperubahan akibat arus dan gelombang modernisasi khususnya

\footnotetext{
${ }^{12}$ Abdurrahman Wahid. tt. Bunga Rampai Pesantren. ttp: CV. Dharma Bhakti, h. 102-103
}

13/bid., h. 103-104 
yang menyangkut model sekolah Barat (sekuler) tersebut, dapat dibuat catatan untuk menjelaskan arah baru kehidupan pesantren:

- Perubahan yang ditempuh pesantren tidak menghapus tradisi yang lama, tetapi sekedar menambahkan dengan sesuatu yang baru, sehingga tradisi maupun kondisi yang lama bisa dipertahankan sambil menerima kehadiran yang baru.

- Cara menempuh perubahan ini memang tidak menimbulkan resistensi yang kuat dari kalangan internal pesantren, tetapi menimbulkan krisis identitas karena belum berhasil mendamaikan kondisi atau tradisi yang lama dengan yang baru sedang masing-masing kondisi atau tradisi itu memiliki watak yang berlawanan.

- Krisis identitas itu mengakibatkan sikap pesantren menghadapi modernisasi menjadi tidak jelas bahkan ambivalen sebagaimana dilukiskan Steenbrink sebagai suatu sikap yang "menolak sambil mengikuti," suatu sikap yang aneh. Secara praktis sikap ini bisa diterapkan tetapi secara psikis menjadi beban moral.

- Respon pesantren terhadap gelombang modernisasi itu tidak dilandasi pertimbangan ilmiah (rasional dan kenyataan empiris) yang matang, tetapi kbih mempertimbangkan faktor politis, emosi dan rasa fanatik sehingga pendirian pesantren menjadi labil atau mudah berubah-ubah dalam garis yang zig-zag.

- Respon pesantren terhadap gelombang modernisasi itu telah memperkuat kocondongan pada penguatan orientasi ekonomi dan serba perhitungan materi seperti masuknya sekolah dan perguruan tinggi, pembentukan tenaga pengajar agama, penegerian madrasah, dan pendidikan dengan uang.

\section{KEBIJAKAN DAN STRATEGI PENGEMBANGAN PESAN- TREN}

Sebagaimana yang dialami dunia Islam pada umumnya dalam mengembangkan peradaban dan kebudayaan senantiasa terhadang problem pertentangan Islam dan modernitas atau tradisi dan modernisasi. Hal ini menjadi problem serius sehingga dunia 
Islam masih kesulitan mengejar kemajuan Barat. Keadaan ini berbeda dengan pengalaman Barat. Muhammad Abed al-Jabiri menilai bahwa Barat bertitik tolak dari ketergantungan kepada tradisi, yakni tradisinya sendiri atau yang diklaim sebagai miliknya. Tapi, ketergantungan itu bukan untuk menjadikan tradisi masa lalu itu beku dan statis, melainkan justru dijadikan sandaran untuk melakukan kritik dan melangkahinya (passing over). ${ }^{14}$

Problem pesantren dalam hal ini juga sama. Pesantren sebagai penjaga gawang tradisi berbenturan dengan modernisasi sebagai suatu kejadian yang tak terhindarkan. Jika Barat telah mampu menghindari benturan itu, sebaliknya pesantren justru dalam posisi berhadapan. Oleh karena itu, kemajuan yang dicapai pesantren sangat lambat. Nurcholish Madjid pernah menilai bahwa salah satu kelemahan pesantren karena kurang bersifat 'ashriy (menzaman). Dia membuat perbandingan dengan Harvard University (Universitas Harvard) yang asalnya merupakan "pesantrennya" orang-orang Katolik kemudian berkembang menjadi Universitas terkemuka di Amerika maupun di dunia. Andaikan perkembangan pesantren seperti Universitas Harvard itu, niscaya nama universitas tidak lagi Universitas Gajah Mada tetapi Universitas Krapyak, bukan Universitas Brawijaya tetapi Universitas Tebuireng dan lain sebagainya.

Sebenarnya, dalam menghadapi modernisasi itu pesantren memiliki resep pemecahan yang tepat sekali, suatu slogan yang selama ini dipegangi pesantren yakni memegangi hal-hal lama yang baik dan mengambil hal-hal baru yang lebih baik ( $a l-$ muhafadhah ala al-qâdîm al-shalih wa al-ahdz bi al-jadid al$a s h l a h)$. Slogan ini dapat menjadi kunci mendamaikan antara tradisi dan modernisasi. Sikap memegangi hal-hal lama yang baik (al-muhafadhah 'ala al-qadim al-shalih) sebagai cermin tradisi, sedang sikap mengambil hal-hal baru yang lebih baik (al-ahdz bi al-jadid al-ashlah) sebagai cermin modernisasi.

${ }^{14}$ Muhammad Abed al-Jabiri. 2000. Post Tradisionalisme Islam, terj. Ahmad Baso, Yogyajarta: LKiS, h. 201-202 
Slogan ini merupakan bekal yang strategis karena berupaya menggabungkan, mendamaikan atau memadukan antara tradisi dengan modernisasi. Sayang sekali prakteknya tidak seimbang. Kalangan pesantren ternyata kelewat batas dalam menjaga tradisi tetapi serba curiga terhadap modernisasi, sehingga upaya mendamaikan tradisi dengan modernisasi itu masih belum berhasil secara maksimal.

Apabila slogan itu diterapkan secara konsisten, tentu tidak terjadi sikap ambivalen seperti tersebut di depan, karena samasama diseleksi. Kata-kata al-shalih (yang baik) dan al-ashlah (yang lebih baik) merupakan kata-kata yang.berfungsi sebagai pembatas dan filter baik terhadap tradisi maupun modernisasi. Kata al-shalih membatasi dan memfilter tradisi sedang al-ashlah membatasi dan memfilter modernisasi.

Oleh karena itu, melalui slogan itu justru dapat dipecahkan problem hubungan antara tradisi dan modernisasi, sehingga pemetaannya tidak lagi memperhadapkan dua pilihan secara kontras antara pendidikan pendalaman agama (tafaqquh fi aldin) sebagai tradisi yang telah lama berjalan di pesantren di satu pihak dan kecenderungan memenuhi tuntutan pendidikan berbasis modernitas di lain pihak. Tetapi justru berupaya menggabungkan keduanya dengan pembatas dan filter masing-masing tersebut. Akhirnya wujud pesantren yang dikehendaki adalah pendidikan tafaqquh fi al-din secara modern.

Melalui slogan tersebut, model pendidikan tafaqquh fi aldin secara modern menghendaki upaya mempertahankan tradisi lama yang baik dan membuang yang tidak baik maupun mengambil modernisasi yang lebih baik (efektif efisien) dan menghindarkan yang tidak baik. Maka dapat dicontohkan tradisi yang perlu dan harus dipertahankan maupun modernisasi yang harus diambil antara lain:

Penggunaan kitab kuning berbahasa Arab sebagai referensi dalam proses pembelajaran karena dapat mengenali serta menguasai khasanah Islam klasik dan mengakrabkan dengan bahasa Arab sebagai bahasa kitab suci atau wahyu. 
- Penguasaan ilmu-ilmu alat seperti nahwu, sharaf, dan balaghah karena sebagai alat untuk menguasai isi kitab berbahasa Arab.

- Penggunaan asrama (pondok) sebagai tempat belajar dan penginapan para santri selama di pesantren karena dapat mendukung secara efektif terhadap penguatan kegiatan belajar bahkan kalau di-manage dapat membangun lingkungan bahasa (bi'ah lughowiyah).

- Penggunaan masjid secara ketat sebagai tempat beribadah karena bisa berfungsi mengontrol kedisiplinan ibadah para santri dan tempat penyucian jiwa dalam rangka proses penerimaan ilmu.

- Hubungan batiniyah antara kiai dengan santri yang terjalin dengan sama-sama mendoakan satu sama lain karena dapat menghubungkan perasaan keduanya dalam proses pembentukan kepribadian.

- Kemandirian (sikap independen) pesantren yang tercermin dalam sikap kemandirian kiai, ustadz dan santri karena dapat memberikan kebebasan untuk berkreasi merumuskan model pendidikan Islam yang dipandang alternatif.

Adapun unsur-unsur modernisasi dari sekolah yang perlu diambil antara lain adalah:

- Penerapan manajemen secara profesional, karena dapat mempertahankan eksistensi lembaga pendidikan yang dimanage dalam rentang waktu yang lama di samping dapat mengantarkan kemajuan lembaga.

- Penerapan kepemimpinan yang kolektif, karena dapat mendistribusikan kewenangan pada masing-masing unit, sekaligus meringankan beban top-leader, melibatkan partisipasi masyarakat pesantren secara aktif, dan menyiapkan kader pengganti yang akan mengendalikan kepemimpinan berikutnya.

- Penerapan sikap krisis, karena dapat mengamati dan menilai sesuatu secara mendalam, mengetahui kelemahan seuatu pemikiran secara jeli, dan memiliki kemampuan tinggi untuk 
membandingkan dan memilih model pembelajaran yang paling efektif.

- Penghindaran pemahaman yang menyucikan pemikiran agama (taqdîs afkâr al-dîniy), karena dapat menjaga kelangsungan atau kesinambungan dinamika pemikiran yang mengarah pada pencapaian pemikiran Islam yang maksimal.

- Penguatan-penguatan epistemologi dan metodologi, karema aspek-aspek ini yang mengantarkan pada kemajuan ilmu pengetahuan dan teknologi, peradaban dan kebudayaan, terobosan dan strategi, keberanian dan kemauan, maupun pemahaman dan pemikiran yang senantiasa mencari pemecahan masalah. Aspek-aspek tersebut selalu menumbuhkan watak pengembang, yang justru menjadi kelemahan utama pesantren selama ini.

- Penerapan keharusan penelitian dan penulisan karya ilmiah, karena di samping dapat memberikan kontribusi terhadap khazanah ilmiah juga dapat mendokumentasikan informasiinformasi penting serta menjaganya dalam waktu yang lama. Tradisi penelitian dan penulisan ini juga menjadi kelemahan pesantren.

- Penggunaan alat-alat teknologi modern karena dapat membantu memudahkan, memperlancar dan mempercepat penguasaan santri dalam proses pembelajaran seperti komputer, lap top, LCD, CD Room dan sebagainya.

Dari pemaparan itu, sebaliknya ada tradisi pesantren yang dipandang kontraproduktif yang perlu dihindari atau setidaknya dikurangi seperti kecenderungan mono manajemen, kepemimpinan individual kiai, sikap pasif santri, pandangan yang menyucikan pemikiran agama, penghafalan materi, tradisi verbal, dan penggunaan alat-alat manual. Sedangkan kecenderungan sekolah modern yang perlu dihindari antara lain sikap ketergantungan pada satu pola sistem pendidikan, sikap individualis guru-dosen serta siswa-mahasiswa, dan terlalu kuatnya penekanan pada pengajaran. 
Dengan demikian, sistem pendidikan pesantren yang perlu dikembangkan adalah sistem pendidikan yang menggabungkan keunggulan-keunggulan tertentu dari tradisi pesantren dan keunggulan unsur-unsur modernisasi dari sekolah sekuler sebagaimana tersebut sehingga benar-benar mencerminkan lembaga pendidikan yang benar-benar memberikan pengajaran, pendidikan, tradisi penelitian dan penulisan karya ilmiah sehingga menghasilkan santri yang unggul keimanannya, intelektualnya, amalnya, akhlaknya, dan semangat pengembangannya. Dengan pengertian lain, pesantren yang perlu dikembangkan adalah sistem pendidikan yang memfasilitas pendalaman agama ( $t a f a q-$ quh fi al-din] melalui pendekatan pembelajaran modern yang bersifat emansipatoris (pembebasan dari eksklusivisme) dan developmental (berwatak pengembang).

\section{KESIMPULAN}

Pesantren sebagai lembaga pendidikan Islam tertua di Indonesia telah memiliki kekuatan bertahan yang luar biasa, dengan merespon perubahan-perubahan dari luar akibat arus dan gelombang modernisasi dan globalisasi. Namun, respon itu menimbulkan dilema seperti krisis identitas.

Oleh karena itu, kalangan pesantren perlu menempuh strategi tertentu dalam menghadapi kecenderungan sekolah sekuler untuk menghindari benturan antara tradisi dengan modernisasi melalui pengejewantahan slogan al-muhafadhah 'ala al-qâdîm al-shalih wa al-ahdz bi al-jadid al-ashlah secara konsisten dan seimbang.

Berdasarkan slogan ini, sistem pendidikan pesantren yang perlu dikembangkan adalah sistem pendidikan yang menggabungkan keunggulan tradisi pesantren dan keunggulan unsurunsur modernisasi dari sekolah sekuler sehingga mencerminkan lembaga yang benar-benar memberikan pengajaran, pendidikan, tradisi penelitian dan penulisan karya ilmiah sehingga menghasilkan santri yang unggul keimanannya, intelektualnya, amalnya, akhlaknya dan semangat pengembangannya. 


\section{Sumber Bacaan}

Azra, Azyumardi (1985) : "Surau di Tengah Krisis: Pesantren dan Perspektif Masyarakat." dalam M. Dawam Rahardjo (ed.). Pergulatan Dunia Pesantren Membangun Dari Bawah, Jakarta, LP3ES.

Azra, Azyumardi (1999) : Pendidikan Islam Tradisi dan Modernisasi Menuju Millenium Baru, Jakarta, Logos Eacana llmu.

Dirdjosanjato, Pradjatta (1999) : Memelihara Umat Kiai Pesantren Kiai Langgar di Jawa. Yogyakarta. LKiS.

al-Jabiri, Muhammad Abed (2000) : Post Tradisionalisme Islam, terj. Ahmad Baso. Yogyajarta: LKiS.

Kartodirdjo, Sartono (1977) : Sejarah Nasional. Jakarta. Balai Pustaka.

Langgulung, Hasan (1988) : Pendidikan Islam Menghadapi Abad ke-21. Jakarta, Pustaka al-Husna.

Ma'shum, Ali (1995) : Ajakan Suci. editor: Ismail S. Ahmad, M. Yoenus Noer dan Nadirin, ttp: LTN-NU DIY.

Mustoko, Sumarsono et.al. (1996) : Pendidikan di Indonesia dari Jaman ke Jaman. Jakarta, Balai Pustaka.

Qomar, Mujamil (2005) : Pesantren dari Transformasi Metodologi Menuju Demokratisasi Institusi, Jakarta, Erlangga,

Wahid, Abdurrahman (1995) : "Pesantren Sebagai Subkultur" dalam M. Dawam Rahardjo (ed), Pesantren dan Pembaharuan, LP3ES.

Wahid, Abdurrahman (1999): "Pondok Pesantren Masa Depan", dalam Marzuki Wahid, Suwendi dan Saifuddin Zuhri (penys.), Pesantren Masa Depan Wacana Pemberdayaan dan Transformasi Pesantren, Bandung. Pustaka Hidayah.

Wahid, Abdurrahman (1980): Bunga Rampai Pesantren, ttp: CV. Dharma Bhakti. 